\title{
Airbnb: the future of networked hospitality businesses
}

\author{
Jeroen Oskam and Albert Boswijk
}

\author{
Jeroen Oskam is based \\ at Research Centre, \\ Hotelschool The Hague, \\ The Netherlands. \\ Albert Boswijk is based \\ at European Centre for \\ the Experience Economy, \\ Bilthoven, The Netherlands.
}

(C) Jeroen Oskam and Albert Boswijk. Published in the Journal of Tourism Futures. This article is published under the Creative Commons Attribution (CC BY 4.0) licence. Anyone may reproduce, distribute, translate and create derivative works of this article (for both commercial and non-

commercial purposes), subject to full attribution to the original publication and authors. The full terms of this licence may be seen at http://creativecommons.org/ licences/by/4.0/legalcode

\begin{abstract}
Purpose - Although networked hospitality businesses as Airbnb are a recent phenomenon, a rapid growth has made them a serious competitor for the hospitality ind ustry with important consequences for tourism and for tourist destinations. The purpose of this paper is to analyse the nature of the phenomenon, its potential further development in the next five years and the impact this developments will have on tourism, on hotels and on city destinations.

Design/methodology/approach - A literature study, combined with scenario workshops and a Delphi panel, were used to map current trends and uncertainties. With this input, future scenarios were elaborated using the Global Business Network ("scenario cross") method.

Findings - Network platforms as Airbnb are often classified under something called the "Sharing Economy", a denomination that obscures their true nature. Airbnb is a challenging innovation to which traditional hospitality will have to respond. Its impact has at the same time led to a call for regulatory policies. The definition of these policies and the evolution of tourism are variables that determine future scenarios. Attempts to ban the phenomenon mean a disincentive to innovation and protect oligopolistic markets; more receptive policies may have the desired results if tourism grows moderately but in booming destinations they may lead to a harmful commercialization.

Originality/value - Until now, Airbnb has been described in conceptual studies about the so-called "Sharing economy", or more recently in empirical studies about isolated effects of holiday rentals. This paper contextualizes the evolution of networked hospitality and seeks to synthesize the sum of its impacts, thus enabling businesses and local governments to define positions and strategies.
\end{abstract}

Keywords Trends, Scenario planning, Hospitality, Sharing economy, Short stay, Tourist pressure

Paper type Research paper

\section{Introduction}

Just a few years ago, the emergence of networked hospitality businesses was hardly a topic of academic nor of commercial interest. With the largest networked accommodation service, Airbnb, now surpassing the major hotel chains in number of beds offered and in market valuation, it is safe to say that many realized the extent of this disruptive business model too late. In this paper we will analyse this development in order to assess its impact in the years to come.

We will first discuss the drivers of growth of digital platforms which explain this disruption in the context of structural societal changes. Short-stay holiday rental by private individuals and entrepreneurs, as opposed to professional and established hotel businesses, is sometimes incorrectly, in our view - categorized as part of something called the "sharing" economy. Our analysis of networked business models aims to demystify that understanding.

While the initial web-driven initiatives in "social travel" revolved around the adventurous and altruistic motivations of offering people a place to stay and sharing experiences, networked hospitality businesses turned the "inviting strangers to your home" concept into a for-profit 
model. With the anecdotal origin of two recent university graduates converting their home into an "Air Bed \& Breakfast" by offering overnight stays on air mattresses during a San Francisco conference in 2007 (Guttentag, 2013), Airbnb created a commission-based web-platform for room sharers and travellers. A few years later, the offer on the company's website goes way beyond air mattresses and people's spare rooms: with Manhattan lofts for $\$ 1.000$ a night, luxury houses in Paris for multiple times that amount or properties in Barcelona for groups of up to 20 people - to name just a few examples - , Airbnb has become a competitor and a disruptor for the traditional hospitality industry. The phenomenon of networked hospitality businesses includes several other companies, such as HomeAway, Wimdu or HouseTrip. Airbnb is the market leader and best documented case in peer-2-peer (P2P)-accommodation; this study analyses the company as a reflection on the networked hospitality phenomenon in general.

With hospitality and tourism experts we looked into the past, current and future impact of Airbnb and similar initiatives. These insights were the basis for future scenarios, in a conceptual exploration that in the first place must become part of the academic discussion on the future and hospitality and tourism. At the same time, our scenarios can have strong practical implications. We hope that they will contribute to constructive policy development for municipalities and other governmental bodies, as well as to strategic answers in the professional hotel industry.

\section{Structural changes in society}

The main drivers for societal change can be considered from four perspectives; technological innovation, sociological, philosophical and an economic perspective.

\section{Technological perspective}

The number, speed and adoption of technological innovations grow exponentially. These continuous innovations follow the law of Moore - according to which processing power doubles every two years - and have a considerable impact on the way we organize our society, our economy, our health care and education. This influences almost all aspects of our lives: the way we communicate, the way we produce energy and the way we distribute. We just only mention innovations in the field of 3D printing, robotics, solar energy, nanotech, biotech, life sciences. The physical world becomes digitalized. According to Rifkin (2014) we are in the middle of the thirdindustrial revolution and we move into the time frame of the Internet of Things. We have become familiar with the internet of communication. Now we are moving to an internet of energy and one of distribution. Three platforms that are migrating at the same time to an Internet of Things and towards a zero cost based society cause an enormous disruption.

\section{Sociological perspective}

Brand and Rocchi (2011) describe the changing ideas around the concept of value. The ideas that have captivated people's mind-sets over the last 60 years have moved from an industrial economy with a focus on product ownership, to an experience economy, to a knowledge economy with focus on self-actualization towards a transformational economy with focus on a higher purpose and searching for meaningful living. From the business perspective, the paradigms shift from mass production, to marketing and branding, towards knowledge platforms and value networks. These processes cause a higher awareness and engagement in our society: social innovation of our educational system, our health care, well-being and transport systems (Green, 2007). On top of that, new communicative technologies enable a total connectivity and enable P2P networks.

\section{Philosophical perspective}

According to Cornelis (1988) the human being unfolds his hidden learning programme through the logic of feeling. The human being nestles itself in three layers of stability. The first is the natural system: the human being is protected and hidden from society. Second is the social regulatory system where rules and norms dictate the prescribed behaviour, the human being is obedient to 
the norm. Cornelis argues that the third layer of stability is entering the phase of deep communicative self-direction. The human being becomes creative and actively determines the course of his life (Boswijk, 2013).

\section{Economic perspective}

Our economy dematerializes; an important shift is taking place in Western economies, with a switch from agricultural and industrial production to services in which experiences and meaning are important. In general terms dematerialization may also be said to refer to the relative reduction in the amount of physical materials required in order to perform economic functions (Herman et al., 1990). There are three areas in which dematerialization finds expression: digitalization, eco-efficiency and intangible aspects of consumption. On the above the economy based on scarcity transforms into an economy of abundance and ubiquity. We are moving from a time frame of possession to the age of access (Rifkin, 2000). The process of fast digitalization is disrupting old business models harder then we realize. Apart and aside from the Internet of Things there is an increasing power shift between consumers and suppliers and their networks. This process makes it possible for some organizations to grow exponentially.

\section{The rise of $\mathrm{P} 2 \mathrm{P}$ value networks}

The rise of the concept of co-creation and co-created value through value networks was initially noted by Allee (2003), Prahalad and Ramaswamy (2004). They are the first to mention the essential paradigm shift between firm centric and client centric, postulating that the process of value creation finds place "inside" the consumer (Ramaswamy and Gouillart, 2010). For the first time the customer becomes part of and he starts to manage his own value chain. The economy is developing into a networked economy instead of the traditional hierarchical structure. Traditional suppliers lose control of their markets if they do not take a crucial position in the digitalized networks. According to Pralahad and Ramaswamy co-created platforms need to fulfil the following four conditions; they need to ensure the DART principle; dialogue, access, risk management and transparency. Partially through new communication technologies and the internet everybody communicates with everybody and everything. Here the democratization of communication takes place and the world breaks open (Ridder, 2011). Consumers become co-creators of value and have the potential to become entrepreneurs by dealing with their assets like solar energy and renting out their houses and apartments (Boswijk et al., 2015).

\section{The rise of exponential organizations}

The dematerialization and digitalization of our society made it possible for organizations to reach far beyond traditional markets. Exponential organizations grow ten times as fast as their market. They function better, are faster and cheaper. Ismail et al. (2014) describe the success factors of these companies as follows: they have a compelling higher purpose, they dare to experiment, they have smart interfaces, they build on community and engagement, manage algorithms, have leveraged assets and empowered autonomous workers. Airbnb, Uber, Etsy, Gitgap are examples of "exponential organizations".

\section{Typology of networks}

To clarify the different types of digitalized value platforms we postulate two dimensions; the first horizontal dimension is the commons vs the private/commercial, the second dimension is open systems vs controlled and closed systems (Figure 1).

Through introducing these two dimensions we identify four types of value networks (adapted from Kostakis and Bauwens, 2014; Bauwens, 2014):

1. In the upper left quadrant we identify open and not for profit systems. Like Wikipedia, Linux. Here one speaks of co-created P2P value. The public benefit is central. There is no other reward than the intrinsic value. 


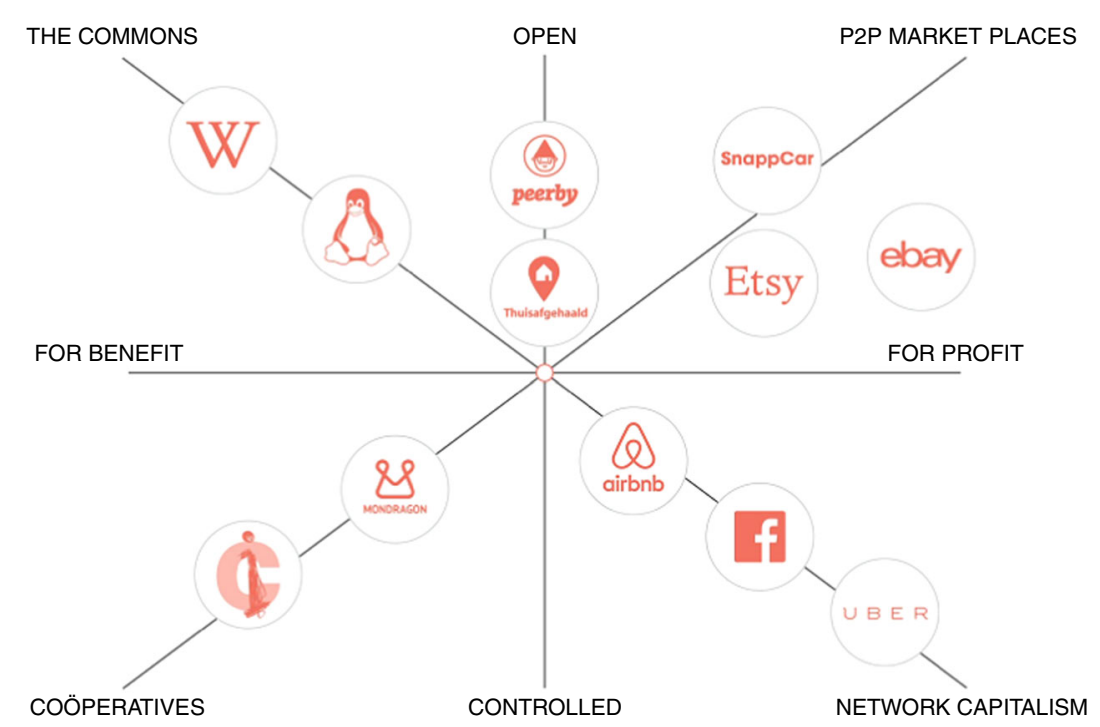

2. On the upper right quadrant we identify P2P social market places based on open systems and with a fine tuned distributed market function.

3. On the left bottom we identify collectives that are characterized through a closed protected system and for the common good. We call these collectives; an example is the Mondragón collective in the Basque Country (Kasmir, 1996).

4. On the bottom right, we identify the network capitalists, they are based on hyperconnected and distributed platforms with a commercial goal.

This classification provides the framework for our analysis of Airbnb as an exponential organization in the networked economy. We need to emphasize the difference between P2P networks that empower individual consumers (Bauwens, 2014) and the overall concept of "networked economy" where connections may be used for mutual benefit but also with commercial intentions. We propose to obviate the term sharing economy because it is a contradictio in terminis and confuses the academic discourse.

\section{Network economy vs "sharing economy"}

Parties like Airbnb and Uber position themselves as part of the sharing or collaborative economy. This positioning finds support in authors as Botsman and Rogers (2011), Botsman (2015) and Gansky (2010), where "sharing" is used as a diffuse concept describing contact and transactions between individual consumers. Frenken et al. (2015) define the sharing economy as consumers granting each other temporary access to underutilized physical assets ("idle capacity"), possibly for money. By parsing his definition into three elements, Frenken et al. claim to distinguish the sharing economy from other economic forms:

1. Sharing is about consumer-to-consumer platforms and not about renting or leasing a good from a company (business-to-consumer). In the latter case we would speak of productservice economy, where a consumer gains access to a product whilst the service provider retains ownership.

2. Sharing is about consumers providing each other temporary access to a good, and not about the transfer of ownership of the good. Thus, the sharing economy does not include the second-hand economy, in which goods are sold or given away between consumers (as occurs on online platforms such as EBay or Facebook). 
3. Sharing is about more efficient use of physical assets and not about private individuals delivering each other a service. After all, physical goods can go unused, but people cannot. Internet platforms that bring consumers together to provide each other with services represent the on-demand economy. An example of such a platform is Task Rabbit, through which you can hire people to carry out work around the house.

Also Rifkin (2014) uses the term "sharing economy" when referring to - what we would preferably call - a hyperconnected economy. While market places connect supply and demand between customers and companies, digital platforms connect customers to whatever (Olma, 2014). The platform is a generic "ecosystem" able to link potential customers to anything and anyone, from private individuals to multinational corporations. Everyone can become a supplier of all sorts of products and services at the click of a button. This is the real innovation that digitalization and digital platforms have brought us. The concept of "sharing economy" should be distinguished from what is traditionally called "sharing". The essence of sharing is that it does not involve the exchange of money. Sharing only happens in the absence of market transactions.

What companies as Uber, Airbnb, Task Rabbit or Postmates have in common is that they are platforms coordinating supply and demand of products and services that in their present form were previously unavailable on the market. Uber is a platform where people looking for a cab quickly find their non-, semi-, and real-professional taxi driver, thus enabling drivers to become entrepreneurial. Airbnb allows people to sublet their houses, Task Rabbit connects supply and demand for chores, Postmates for deliveries, Instacart for grocery shopping. While it might be convenient to make use of these services, they have absolutely nothing to do with sharing. They stand for a digitally enabled expansion of the market economy, which, again, is the opposite of sharing.

\section{The case of Airbnb}

Airbnb started in 2008 as a simple proposition that combined economic benefits for travellers and for residents of tourist areas. As Molly Turner (2013), Global Head of Civic Partnerships at Airbnb, explains: "Our business model is based on people who can't afford their homes and need extra money, so they rent out their homes". The company's success can also be explained by the secondary effects of this basic proposition:

- a compelling experience value proposition: "Live like a local";

- easy access and the establishment of a trusted marketplace, through engagement and community (P2P);

- the power of the network, leading to increasing scale advantages; and

- leveraged assets (Ismail et al., 2014; Boswijk et al., 2015).

So far, especially the experiential aspect - staying over at someone's place, allowing for contact between visitors and residents and for "off-the-beaten-track" tourism - has made it tempting to compare the concept to actual "shared" activities, especially Couch surfing. This has led to the erroneous classification or Airbnb, where private individuals exchange economic goods - tourist accommodation - and both pay a business that has created an enabling platform, as "sharing". The concepts and the economic effect of Airbnb are radically different than the shared use of an asset as the exemplary power drill (Botsman, 2010/2015):

1. It can be discussed whether housing is an underutilized asset. In any case, in those instances where a resident leaves his house to rent it, we see substitute use rather than additional use;

2. The demand for holiday rentals is far more elastic than for the typical power drill; and

3. Unlike underutilized power drills, the short-stay rental of private homes entered in direct competition with an existing market.

The economic effect has made Airbnb disruptive for the traditional hotel industry. In the next sections we will analyse the future impact of Airbnb on hotels, on tourism and on destinations. 


\section{Literature review}

\section{Business model}

The spectacular growth of Airbnb and similar initiatives is still too recent to be thoroughly reflected in academic literature. In general, the limited number of studies either study the phenomenon as a showcase of the emergent "sharing economy", or they analyse specific characteristics of the offer: its business model and disruptive effects, consumer adoption and trust, positive and negative impact on city destinations and regulation issues. To keep pace with its rapid and disruptive growth, it is necessary to combine academic insights with trends and developments identified by industry reports, general news media and trade journals.

If we look at studies on Airbnb as part of the networked economy, two explanations of its success are dominant: idealistic motives and, in particular, the authenticity of P2P contact in the accommodation experience, on the one hand, and by economic benefits for hosts and guests, on the other, Airbnb and other forms of P2P travel are categorized by Botsman and Rogers (2010) as examples of the "Collaborative lifestyle" that combines the "benefits of ownership with reduced personal burden and cost and also lower environmental impact". The desire for social interaction is often seen as the main driver behind the growth of the phenomenon (Gansky, 2010; Ikkala and Lampinen, 2015). For Rothkopf (2014) Twitter and Airbnb are ways of "connecting with others in ways that are both creative and progressive". Marriott CEO Arne Sorensen is quoted highlighting the "taste of the authentic neighbourhood life" as the reason for Airbnb's success (Tuttle, 2015).

Nevertheless, if we go from these conceptual approaches that seek to explain and advocate the emergence of the collaborative economy, to studies into the actual motives of participants in the phenomenon, idealism seems to play a secondary role. For guests, Airbnb is primarily a low-cost option (Guttentag, 2013; Liang, 2015). Airbnb hosts are also driven in the first place (IPSOS, 2013; Holte and Stene, 2014; Hamari et al., 2015) or to an important degree (Glind, 2013; Stors and Kagermeier, 2015) by financial motives. This financial motivation does not necessarily contradict the social or environmental advantages consumers may seek in sharing; however, an important aspect to watch for the future of Airbnb is whether its economic effect will still be that "people have to buy less goods while still having access to the services of those goods" (Glind, 2013, p. 30).

This economic aspect is in fact crucial for the business model of Airbnb. P2P rentals follow the same business models as traditional B\&Bs, except for the impact of the Airbnb community and the promotional advantage of the worldwide platform. Compared to hotels, Airbnb hosts offer competitive pricing because in the case of private residences fixed costs as rent and electricity are already covered, because of minimal labour costs, the fact that Airbnb revenue is usually an additional income, and because stays are usually not taxed. The business model of the platform itself is based on commissions paid by guests (6-12 per cent) and hosts ( 3 per cent) (Guttentag, 2013).

P2P accommodation can therefore be seen as a two-sided market in which the platform facilitates transactions and adds value to both sides by bringing both buyers and sellers "on board" (Rochet and Tirole, 2004). The price composition favours or "subsidizes" the host side in the case or Airbnb, as part of the company's growth strategy: sellers are incentivized to join the network, thus maximizing its attractiveness to accommodation seekers. Unlike in more traditional business models, in the case of two-sided platforms growth leads to increasing returns to scale, as users will pay more for access to a bigger network (Eisenmann et al., 2006). It is therefore not surprising that the platform, as it keeps adding listings to its offer (currently 1.5 million) shows a continuous and explosive growth, with a forecasted number of 80 million nights booked in 2015 (Somerville, 2015).

To make this business model work, Airbnb had to address three key issues: getting hosts and guests on board, avoiding a direct negotiation and establish trust as a condition for transactions to take place. As indicated by Guttentag (2013), the marketing power is what set Airbnb apart from the traditional vacation rental market. The "sharing" philosophy and the image of a warm and authentic community - as transmitted mainly in video testimonials - has been essential to persuade hosts and guests to join the network (Stern, 2010; Yannopoulou et al., 2013). But at the same time, direct transactions between the two parties had to be prevented as this would lead to a one-sided business (Rochet and Tirole, 2004). The company does this directly through an 
algorithm that blocks messages containing phone numbers or e-mail addresses, as well as by offering services to facilitate transactions such as credit card payment, pricing tools and insurance (Consigli et al., 2012; Hill, 2015).

Trust is an important concern for internet transactions in general, and more so if the transaction entails admitting strangers to one's private environment. Obviously traditional hotels have a competitive advantage because they reduce risks through standardization, safety regulations and business reputation. Airbnb "horror stories" are abundant on the internet, as well as articles assessing the risks (Nicholls, 2015; Folger, 2015; Lehr, 2015). Kohda and Masuda (2013) suggest that the value created by sharing services resides precisely in the absorption of the risks of customers. Trust represents a value as "reputational capital" allows for higher prices (Ikkala and Lampinen, 2014). The mutual review system of hosts and guests is seen as the foundation of trust in Airbnb transactions (Finley, 2013; Guttentag, 2013; Lehr, 2015), even though precisely the reciprocity of the system is considered to undermine its reliability (Slee, 2013; Zervas et al., 2015).

\section{Impact}

Airbnb is expected to drive hotel rates and revenues down as the additional supply will affect the distribution of power in the market (Consigli et al., 2012; Jordan, 2015). According to Merril Lynch, as of 2017 oversupply will negatively affect hotel business values (Huston, 2015). The impact of Airbnb on hotel revenues has been quantified in a study by Zervas et al. (2014): the authors estimate a 13 per cent loss of room revenue for Austin and a 0.35 per cent decrease in monthly hotel room revenue for every 10 per cent increase in Airbnb listings for Texas in general. The same authors observe that lower-end hotels and hotels without business facilities suffer most. A study on the effect of Uber on taxis in New York and Chicago shows, in a similar fashion, a reduction of complaints as the alternative offer grows, which can be interpreted as a clean-up of the system: taxis are forced to improve quality or they are driven out of business (Wallsten, 2015).

It is a general understanding that Airbnb "is bad for hotels but good for tourism". The company asserts it is complementary to traditional hospitality since around 70 per cent of their offer is outside central hotel districts (Airbnb, 2013a). Merril Lynch analysts, on the other hand, consider that a considerable part (43-67 per cent) of Airbnb listings compete directly with the traditional hotel offer as they are not shared spaces (Huston, 2015). Guttentag (2013) suggests that spending may in fact suffer because of cheaper accommodation, while also the creation of additional income rather than full-time jobs may hurt the hotel industry, a finding that was corroborated by a study in Spain (EY España, 2015). A series of impact studies was commissioned by Airbnb itself. These contain estimates of economic impact, varying from $\$ 56$ million of generated economic activity for San Francisco in 2012 (Airbnb, 2012) to \$1.15 billion for New York in 2014 (Airbnb, 2015); jobs generated - the latter presumably derived from the first - a comparison of Airbnb and hotel guests spend, and host data such as their economic background, monthly Airbnb earnings (around \$600, or $\$ 130$ per night rented) and the percentage of hosts who share their primary residence (between 80 and 90 per cent). As for the guests, the studies report an overwhelming majority aspiring to "live like a local", and percentages between 27 and 35 of visitors reporting they would not have stayed if there was no Airbnb. Finally, the studies on Boston and Los Angeles report important environmental effects (Airbnb, 2014b, c).

The data provided by Airbnb have not been corroborated by independent studies, and they are not fully homogeneous for the different destinations. Except for the latest New York study 760,000 visitors - tourism volumes are not reported, which makes it hard to assess the impact estimates. Most data seem to be based on host and guest surveys (Airbnb, 2013f). While on the one hand the accuracy of these answers can be questioned (e.g. amount of earnings and spending), on the other hand some of the answers seem hardly relevant: if 93 per cent wants to "live like a local" (Airbnb, 2013b), to what extent would such a question reflect customer behaviour? For the location of Airbnb listings - 96 per cent outside traditional hotel districts (Airbnb, 2014a) - a definition of where these districts are would be essential. For the beneficial environmental effects, one would expect a thorough explanation.

The reports insist that the vast majority of Airbnb hosts are non-commercial sharers of their primary residences. However, it can be discussed whether these percentages reflect the nature 
of Airbnb operations; in this case the number of property listings rather than the number of hosts would be relevant. This discrepancy was also identified in the report issued by the New York State Attorney General (2014): "the remaining six percent of hosts dominated the platform [...], offering up to hundreds of unique units, accepting 36 percent of private short-term bookings, and receiving $\$ 168$ million, 37 percent of all host revenue". In other cities we probably have similar concentrations: in Amsterdam "multilistings" are 24.8 per cent of the offer (Cox, 2015), while in Barcelona 2.5 per cent of hosts control 30 per cent of entire apartment rentals and 60 per cent are offered by users with more than one listing (Arias Sans, 2015).

A study commissioned by the Spanish hotel industry questions the panorama depicted by Airbnb and draws conclusions completely opposed to those presented by the company. The Airbnb offer concentrates in tourist city centres more than traditional accommodation (73 vs 42 per cent). This leads - at least, in a causal relation suggested by the report - to housing price hikes that expels residents from tourist areas: for instance, in Barcelona's Ciutat Vella the average sales price increased 24.5 and 3.6 per cent of the resident population was lost. Rather than attracting new segments, the P2P visitor has a similar profile as the traditional hotel guests; the choice is mainly motivated by saving costs and only marginally by the experience. The economic effect is 84.4 per cent lower, considering that the visitors spend €20.30 less on accommodation, €16.70 less on restaurants, retail and entertainment and their indirect impact is $€ 31.20$ lower. The direct and indirect employment effect of P2P travel is 9.8 jobs created per 100 beds, vs 53.3 jobs per 100 beds in traditional accommodation (EY España, 2015).

The growth of Airbnb is often linked to the protest movement against tourist pressure in cities as Barcelona, Amsterdam and Berlin. The volume of Airbnb users does not suggest a causal relation (Kagermeier et al., 2015), but the emergence of P2P travel and residents' annoyance with tourism seem to be both rooted in increased mobility and low-cost travel (Hooper, 2015). If in the social and cultural impact of tourism we distinguish increased availability to facilities - infrastructure, retail, entertainment - on the positive side, and increased competition for the use of these and previously existing facilities - e.g. parking space - on the negative, the frequent mention of Airbnb in recent debates becomes understandable: P2P travel does not add amenities - instead, it explicitly claims to intensify the use of existing local facilities - whereas commercial hosts - as opposed to those who share their primary residences - compete with residents on the housing market (Quijones, 2015; Croft, 2015). This may lead to the displacement of residents and an increase in rental costs, as has been noted in New York and San Francisco (New York State Attorney General, 2014; Zervas et al., 2014; Sabatini, 2015).

These disadvantages may be amply compensated, as the Airbnb (2012, 2013b, c, d, e, 2014b, 2015) studies indicate, by the economic impact of tourist spend in non-tourist neighbourhoods. Nevertheless, a recent study in Berlin has shown that these effects in non-centric neighbourhoods are limited, especially for retail (Kalandides et al., 2015). If the impact is reduced to the indirect effect of residents spending their additional income, the conclusion must therefore be that the main financial beneficiaries are the Airbnb hosts themselves. This means that commercial hosting and gentrification reduce the equal access of hosts to this market and eventually may sharpen socio-economic differences in and between urban neighbourhoods.

\section{A three sided market?}

The Airbnb investment in research conducted by renowned consultancies can be interpreted as part of a marketing strategy aimed at destinations. The message this apparently has to get across is: cities benefit by increasing the number of visitors, by spreading them over the cities and by financially empowering non-traditionally employed residents, such as new business starters. This explains that while in some cities - New York, Barcelona - authorities stress the commercial and socially undesirable aspects of short-term rentals (New York State Attorney General, 2014; Soriano, 2015; Cogolludo, 2015), other cities as Portland and several Dutch destinations have embraced P2P travel as a means to simultaneously promote tourism and social innovation (Kirkland, 2014; Oates, 2015; Bahceli, 2015; Kok, 2015). A benevolent interpretation of P2P initiatives is not only supported by the studies issued by Airbnb, but also by strong lobbying investments reported for companies as Airbnb and Uber (Guttentag, 2013; Sottek, 2014; Lehr, 2015; Vekshin, 2015). 


\section{Regulation}

The reaction to the emergence of $\mathrm{P} 2 \mathrm{P}$ accommodation by authorities and the marketing and lobbying response by Airbnb are moves in the regulation debate. The regulation void - or the difficulty to enforce existing rules - is being approached from three different angles. Its most visible manifestation affects the authorities themselves: this is about if and how tourist and other taxes should be imposed on Airbnb (Maxfield, 2015; Kaplan and Nadler, 2015; Vincent, 2015; Posthumus, 2015). Directly related to this subject is the protest against unfair competition on behalf of the industry (EY España, 2015; Kagermeier et al., 2015). To protect residents, housing regulations limiting rental days apply in cities as New York and Amsterdam (Coldwell, 2014; Dickey, 2014; Tienkamp, 2015; Vekshin, 2015), or prohibiting unregistered accommodation altogether in Barcelona (Cogolludo, 2015; Soriano, 2015). Housing stock and rental fees are the focus of the German debate around Zweckentfremdung or "usage alienation", although several studies relativize the actual vs the perceived effects of holiday rentals (Ziegert, 2013; Füller and Michel, 2014; Blickhan et al., 2014; Kagermeier et al., 2015). The protection of the hosts' interests and liabilities vis-à-vis Airbnb has been analysed by McNamara (2015). Finally, there are consumer protection issues (Nicholls, 2015). It remains to be seen, however, whether new laws and regulations can be effectively enforced: in San Francisco, out of 5,000 Airbnb hosts only 455 registered with the city's Planning Department (Marzorati, 2015).

\section{What is ahead?}

Airbnb is projected to double bookings to 80 million in 2015 (Somerville, 2015) and grow to 100 million beyond 2016; with a 40-50 per cent growth in listings per year, Airbnb could make up 3.6-4.3 per cent of accommodation inventory by 2020 (Huston, 2015). Whereas initially the affected segment were the lower-priced hotels, and hotels not catering to business travel (Zervas et al., 2014), Airbnb's aspirations to enter the business market (Kurtz, 2014; Takhur, 2015) will suppose a further competitive threat to the hotel industry. Potential expansion opportunities for Airbnb can be found in new geographic areas or in new offers outside the current business model, such as non-accommodation spaces (Consigli et al., 2012). At the same time, strategic countermoves by hotel companies and OTAs emulating the P2P offer can be expected (Schaal, 2015a, b).

\section{Future scenarios for networked hospitality}

\section{Process and methodology}

To outline future developments in the networked hospitality business, we have chosen a deductive approach that "specifies the scenarios in the set in terms of scoping outcomes of a few (two or three) critical uncertainties, selected as scenario dimensions" (Van der Heijden, 2005, p. 243). This is the most generalized scenario method, also known as Global Business Network method (Bishop et al., 2007), in which certain drivers appear as constants while the two main uncertain drivers distinguish four scenarios (Van der Heijden, 2005; Yeoman et al., 2012; Enger et al., 2014).

Crucial input is obtained in the scenario crafting process from stakeholders and experts (Yeoman and McMahon-Beattie, 2005; Postma, 2013). In October 2015, 12 hoteliers, hotel investors and representatives from travel and destination management organizations from the Amsterdam area participated in discussions on the future of networked hospitality businesses. In view of the explosive growth of the phenomenon since 2007, a time horizon of five years was chosen. The first workshop was organized as a structured discussion in which input was captured with Spilter moderation software. Participants exchanged views on the main changes, future threats and opportunities for hotels and for tourism in the light of the growth of Airbnb. Subsequently, these views and opinions were classified for their expected impact and uncertainty.

Simultaneously, a digital Delphi panel was organized with a wider geographical spread and with a total of 31 hoteliers, destination marketers and consultants. The main conclusions of the first workshop were used to formulate five questions; the questionnaire focused on the evolution of P2P accommodation to address some of the issues that had become less elaborated in the first discussion. The combined results of both panels allowed the researchers to identify, along with a 
number of trends and developments that were considered highly probable, two drivers for the future evolution of which there was no consensus. These uncertain drivers were chosen as scenario axes as a way to reduce the complexity of future events by crafting four "extreme" scenarios. In a second workshop, the outcomes and scenarios were again discussed and revised with the same expert group.

\section{Drivers for change}

Hotels. Technology and data are seen as the main drivers for change for the hotel industry. Whereas not too long ago their influence would be sought in the visible presence of gadgets in hotel operations and guest entertainment, now they are considered to be rather enablers of new business models and customization. A "currently unimaginable connectivity" is expected, as well as a seamless integration between virtual and offline in hotels. "High tech" will be combined with "high touch", a personalized approach of the hotel guest.

Whereas today hotels merely pretend to do so, the hotel of 2020 will really focus on the guest experience. Hospitality employees become experience managers. Review scores outweigh traditional indicators as ADR. Guest experience will become an important element in real estate valuations.

Hotels will no longer seek to just "put heads in beds"; facilitating meetings between guests and between guests and locals will become an important part of their concepts. The attention will shift from rooms to public spaces. The distinction between business and leisure travel will be blurred. Local communities will become involved in hotel activities. New hotels will be located preferably in existing buildings. Hybrid concepts - e.g. hospitality and care - will appear, as well as collaborations with cultural organizations or creative businesses.

Guests. Besides the obvious demographic and socio-cultural developments - millennials, BRIC guests - the mentioned trends also determine the behaviour of future hotel guests. This guest is in control of the organization of his or her trip, will expect a well-designed experience and usability of his or her own device to operate room facilities and other services. This critical guest has chosen from a wide array of accommodation options, writes reviews and decides to become a fan, or not. As experienced travellers, future tourists move away from standardized offers and seek the local contacts and events they may have become used to using Airbnb.

But maybe the most important consideration about guests is that there will be many more of them. The general growth of tourism predicted by UNWTO, the opportunities of low-cost travel and the concentration of tourism on city destinations will help repeat the impressive growth figures a city as Amsterdam has seen in recent years. This increased demand will contribute to openness to non-traditional accommodation concepts.

Destinations. Obviously, increased visitor numbers will take a toll on cities. Tourism weariness will continue to fuel the debate in destinations as Amsterdam, Barcelona and Berlin. Tourism will spread both as a result of deliberate policies and as a natural consequence of displacement by tourist numbers. This will have a positive effect on the economies of peripheral neighbourhoods but also contribute to gentrification.

Meanwhile, globalization and cultural convergence will blur the differences between cities. This "Starbucks effect" and its counterpart, the search for authentic experiences, are two sides of the same coin. "Disneyfication" - the programmed forging of mock authenticity - is the result of both.

Airbnb. Whether Airbnb will successfully enter the business market is not really a question, especially in the case of generation $Y$ travellers for whom the separation between work and leisure time is diffuse. P2P travel becomes mainstream, and with a growing offer and raised standards it will continue to expand their market share especially at the expense of the lower-end hotels.

Regulatory measures taken to control or even ban P2P travel and the extent to which they are successful will constitute an important driver for the future of Airbnb. Such measures may affect the platform in different ways: they may restrict certain activities, reduce revenue through taxation and impede growth by scaring away both guests and hosts. The control of vacation rentals and 
the enforcement of regulations will become more effective as authorities may adjust their legal power, develop expertise and start using tools as web scrapers.

In scenario planning we speak of "wildcards" for uncertain, but high-impact events. The documented Airbnb "horror stories" involve property damage and scams. An incident involving physical violence, injury or death - for host or guest - may be an unlikely wildcard at the individual transaction level, but has become statistically unavoidable for the total of P2P travel. Such an event will no doubt cast a shadow over the review-based trust model of Airbnb. The news itself and subsequent regulatory measures may seriously hamper growth.

\section{Input generated in the Delphi round}

Five questions regarding expected developments for the next five years were submitted to a group of 31 experts[1]. Their reactions can be analysed as follows:

How do you believe Airbnb will develop in the next five years? The general expectation is a further growth in the next five years, with Airbnb expanding its market share and entering new activities, with hotels starting to use the platform more and more to promote unsold rooms. This will lead to a further commoditization of travel. Stricter regulations will become unavoidable. Some respondents expect the market to mature, while others even foresee a decline because of tight regulations.

Do you see new players enter this market? The hotel and tourist industry itself is mentioned by some respondents as a potential entrant, with the recent example of TUI looking for holiday apartments in Spain. Also, business concepts similar to Airbnb and pop-up concepts can be expected, as well as spin-offs in the use of existing buildings to connect people. Finally, some respondents predict a return to actual "sharing", with Couch surfing as an example.

Which regulatory measures do you expect to become generalized in the next five years? All responses mention taxation and security. Consumer protection, housing stock considerations and unfair competition are seen as other motives, or even specifically the desire to "kill Airbnb": "We should expect some Airbnb providers to be very publicly arrested, tried and fined/jailed in order to make examples of them". Finally, one respondent calls for self-regulation.

What will be the main disruptive force in hospitality in the next five years? This open question leads to a wide array of different answers. Changes in distribution channels, with a hegemonic position for Google, is one of them. Consumer awareness, need for individualization and blurring are changes on the demand side, as well as a strong growth in Asian visitors. Different technological changes, among which faster and more efficient air travel are suggested. Economic changes are cheap travel stimulating tourism, or a major recession reducing it.

Which strategic reaction do you expect in the next five years in the hotel industry? The most common answer to this question is for the hotel industry to emphasize service as its distinctive feature. More attention to the guest experience and customization is expected to appeal to the Airbnb guest. Hotels can be expected to start using Airbnb as a sales channel, or to emulate the platform's offer: "Possibly, a new breed/brand of hotel may emerge in which an established company (say Hilton as an example) offers not one hotel in Amsterdam with 400 rooms, but 50 micro hotels distributed throughout Amsterdam, each one between 15 rooms, fully serviced, centrally managed, and all branded as 'Air Hilton'”.

\section{Scenarios}

The success of networked platforms as Airbnb is caused by a number of big and constant drivers as technological advancements, socio-cultural change and globalization. These drivers will certainly continue to fuel the phenomenon in the near future. Uncertain or variable drivers may, however, steer the evolution of P2P travel in different directions. As identified in our literature study and industry debate, the major unknown is the scope and effect of future regulations. At the moment two extremes - plus in-between shades of grey - become manifest in different cities: while some seek to ban Airbnb and short-term rentals altogether, other cities embrace the phenomenon and cautiously address tax and security excesses. How Airbnb evolves will also 
depend on tourist demand: in highly popular destinations the role and impact of holiday rentals will differ from cities with a more modest tourist economy. Even though tourism growth cannot be considered an uncertainty at global level, this will cause variances at local level.

Both distinctions lead to four extreme scenarios. The intention of these is not predictive; they depict plausible chains of cause and effect and allow for an evaluation and discussion of the advantages and disadvantages of each situation (Table I).

As a next step in the scenario process, these drivers are worked into narratives that illustrate the most relevant drivers and uncertainties reducing their complexity (Lindgren and Bandhold, 2009). These narratives must be meaningful, plausible, imaginative and novel (Yeoman et al., 2012).

Table I Future scenarios for Airbnb impact

\section{Demand is stable}

(1) Status quo

Second tier tourist destinations that, apart from seasonality, attract constant visitor numbers. Closed markets with a limited number of well-known city hotels. Prices are stable except for the occasional event or congress when hotels maximize profits or - as the Spanish appropriately say - "make their August". It is also on these occasions when city authorities are somewhat more permissive towards P2P rentals, which absorb the excess demand

Outside the peek moments there is no room for alternative accommodation. Hotels and authorities join forces to denounce and shut down illegal shortterm rentals. Hotels follow trends to keep up with guest expectations

(3) Exclusivity

City destinations where tourism weariness inspire policies to decrease visitor numbers. Traditional hotels are protected and have an oligopolistic market control. Price hikes during events and high season. Low-cost tourists and students start avoiding the destination; affluent visitors, especially those from new markets, take their place

Hotels have no incentives to innovate and adapt to upscale markets and new visitors. Tourists drive prices in restaurants and local retail up. Illegal P2P rentals pop up like mushrooms to benefit from tourism; they get a "hit-and-run" character as they are being shut down as soon as they are detected

\section{(2) Experimentation}

Second tier destinations that are not traditionally considered tourist attractions but that want to refresh their image and stimulate tourist activity. The objective is to attract niche tourism. Non-traditional accommodation is seen as a way, or maybe even a condition, to become noticed by the desired type of visitors

Neither are these visitors a market, nor is alternative accommodation considered a threat, for the city's traditional hotel sector. On a limited scale - because of the niche character of tourism innovative businesses and hybrid hotelP2P concepts appear. There are no large scale P2P "multilistings"

\section{(4) Commercialization}

City destinations that embrace booming tourism as an important economic sector. The growing size of the pie opens the market for new entrants. Innovative hotel types emerge, as well a full array of P2P accommodation: from basic to high-end luxury accommodation

Growth opportunities attract commercial parties, leading to a limited number of providers with "multilistings" responsible for the larger part of the P2P-offer. The suitability of a property for $\mathrm{P} 2 \mathrm{P}$ rental becomes priced in in rental fees, practically obliging residents to offer their houses as P2P accommodation. The result is gentrification of tourist areas and displacement of residents 


\section{Status quo: Stuttgart 2020}

Stuttgart is an example of a mid-sized European city with modest tourist activity and with a hotel industry mainly catering to business travellers. In 2015, the Airbnb offer was numerically irrelevant. Nevertheless, expected pressure on the housing stock led to a strict "usage alienation prohibition". Social control in resident areas rather than enforcement of the law prevented Airbnb from becoming important in the city.

The city experiences a steady growth and receives more than five million overnight stays in 2020. With business tourism, congresses and shopping as most important reasons to travel, the city targets traditional tourist segments. For the city's hotels this is, in 2020 as in 2015, business as usual.

\section{Experimentation: Portland 2020}

In 2014, Portland, Oregon, reached an agreement with Airbnb. The purpose of the agreement was not only to collect taxes and to impose basic safety regulations; Travel Portland also closely cooperated with the rental company to promote the city internationally. Unlike a German business centre, the Pacific city's "hipster appeal" matches the image of non-traditional holiday accommodation.

In a virtuous cycle, the urban small-business, "maker" culture attracts millennial, "indie" visitors and the tourism this generates boosts creative hospitality concepts. Tourism thus contributes to the culture and liveability of the city. The risk authorities and residents should watch out for, is that the city can become a victim of its tourist success. Excessive growth will threaten the small-scale character and authenticity of its tourist sector, and turn the city into a mainstream first-tier, commercialized destination.

\section{Exclusivity: Barcelona 2020}

Growing irritation with mass tourism, speculation and the Easyjet-set culminated in 2015, when the city announced a moratorium on hotel investments and a harsh crackdown on illegal short-term rentals. Frozen supply and growing demand allowed existing hotels to raise rates. Since new hotels could not be built, investors concentrated on upscaling two and three-star hotels. The city that until then had been a favourite of nightlife loving millennials and international students, became prohibitively expensive for visitors other than big company expats, wealthy Middle-Eastern and Asian tourists and cruise tourists. By 2020, the city had changed into a new Monte Carlo.

Unfortunately, the new tourists also lifted cost levels in retail. The souvenir stores and fast-food outlets that symbolized the "old" tourism had been replaced by design and jewellery stores. Despite the positive economic impact this had on the city, the local authorities faced the same challenge even more than before: how to avoid tourism from displacing local residents from the city centre?

\section{Commercialization: Amsterdam 2020}

Amsterdam had embraced P2P rentals during the financial crisis when it helped home owners afford their mortgages. Airbnb was also seen as a means to increase visitor numbers and to spread tourist spend, but also the nuisance, over the city. The city had always appealed to young and hip visitors looking for experiences off the beaten track. A well-supervised and safe offer of alternative accommodation would underscore that image.

Initially things worked out this way. The abundant availability of non-traditional accommodation also inspired numerous innovative hotel concepts and had spin-offs for other creative businesses. But residential rental prices went up as landlords started to include an "Airbnb premium" in popular tourist areas. Tourism growth meant an unneglectable investment opportunity for investors, who by purchasing properties started building portfolios of popular Airbnb listings. In 2018 Chinese investor Hui Wang, former owner of a Dutch premier league football club, bought the larger part of the popular Pijp district. New tenants were now offered ten-month contracts. Not unlike a time-share construction, this neighbourhood would thus be entirely available for holiday rentals in the city's peak months. 


\section{Conclusions and discussion}

Networked hospitality businesses have emerged in recent years and, although primarily driven by economic benefits, they have brought disruptive innovations to the offer of tourist accommodation and to how visitors experience their stay in a destination. These innovations became possible thanks to the creation of network platforms, which enabled users to share underutilized goods, but which also can be used for economic transactions. Airbnb is an example of a for-profit P2P network platform. Airbnb competes with traditional hotels on price - and initially in particular hurt two and three-star hotels on the leisure market - but it also had an experiential value that enthused many travellers: the surprise of a diverse offer, contact with locals, being part of a community and staying in residential neighbourhoods. Meanwhile, the digitalization of the marketplace and the network or two-sided business model allowed for an exponential and on-going growth. This growth threatens the market share of traditional accommodations, puts pressure on housing markets and it contributes to tourist nuisance to residents, although this effect may be exaggerated in popular perceptions.

The appeal Airbnb has for a broad range of travellers - including business travellers - spurs innovation in the hospitality sector. Experiential elements of Airbnb are adopted in new hotel concepts:

1. customization and personalization: a shift from SOPs to personalized attention and guest experiences;

2. uniqueness of the offer: budget hotels emphasizing unusual design and high-quality F\&B offer;

3. use of existing buildings: repurposed buildings, the original function of which becomes part of the experience;

4. community building between guests and with locals; social innovation: F\&B outlets or events aimed at visitors and residents; and

5. integration into local economies: connection with neighbourhood businesses and employment or trainings in less privileged areas.

In the future we may see further emulations such as branded apartment rentals, as well as the use of Airbnb as an additional sales channel. Further study is required to see whether such innovations - concepts as BeMate, Yays or Zoku - will succeed in regaining Airbnb market share by combining the appeal of local experiences with the advantages of professional hospitality. At the same time, the evolution of networked hospitality companies will have to be monitored; in particular, the success of these companies on the business market, as an important early warning for a further erosion of traditional hotel brands. Further disruptions may derive from their potential to invest in cross-overs such as Online Travel Agents or in any other element of the guest journey.

The platform has grown explosively amidst a regulation void, a situation local governments are seeking to address. Key issues governments and city destinations will face are:

1. Taxation: can unregistered Airbnb visitors be taxed just as registered hotel guests? Can Airbnb income be established and taxed?

2. Visitor streams: while Airbnb is not the cause of increasing visitor numbers, it creates an additional complication. How can cities measure the amount of visitors in order to manage tourist streams?

3. Information ownership: the fact that Airbnb does not disclose visitor and host information, gives the company leverage in negotiating regulation issues with cities.

4. Safety: traditional hospitality companies are subject to regulations to ensure the safety of guests, employees and residents. How can these be enforced for Airbnb properties?

5. Consumer protection: besides safety concerns, are consumers entitled to the same kind of protection in transactions with private hosts as with commercial organizations? 
6. Fair competition: the traditional hospitality industry calls for a level playing field by enforcing the same type of regulation - and corresponding investments - to Airbnb hosts and hotels.

7. Housing market: Airbnb gives residential properties a partial or full commercial use. What will be the effects on housing availability and pricing? Will this mean the end of zoning plans?

Airbnb has responded to these claims with policies in this direction for their hosts and an active marketing and lobbying policy highlighting the advantages of Airbnb: economic impact, spreading tourism to peripheral neighbourhoods and generating additional income for nontraditionally employed residents. As a result, some cities have adopted policies for a controlled expansion of short-term rentals, while others have sought to restrict the phenomenon.

These positions will determine the future evolution of short-term rentals. Another variable will be the evolution of tourist demand. Strong growth opportunities will entice investors to enter the holiday rental market. This will exacerbate the undesirable effects of Airbnb: unfair competition between traditional and unregulated accommodation providers, pressure on the housing market and touristification. Four different scenarios illustrate the extreme outcomes of these variables. Destinations where vacation rentals are banned will disincentivize innovation in their hospitality sectors. They may see an unchanged market if growth is limited ("Status quo"), but also an oligopolistic market and gentrification ("Exclusivity") in more popular destinations. More permissive regulations can have the effects Airbnb depicts - positive economic and socio-cultural impact, support for start-ups, small-scale tourism - in moderate growth destinations ("Experimentation"). But for high-demand destinations the results can become catastrophic ("Commercialization").

This means that there is no "one-size-fits-all" future vision of short-term rentals, and that hospitality and tourism professionals as well as policy makers should consider the characteristics of their destination. As a general rule it is not sensible to neglect business innovations. As many contemporary examples show, regulations mainly aiming to prevent innovations embraced by consumers are doomed to fail, and so are the business models they attempt to protect. However, certain regulatory measures seem justified to protect the interests of visitors and locals; it is reasonable to demand that rental businesses as well as hosts comply. The effects of different regulatory policies should be evaluated by monitoring indicators as visitor numbers - if these can be accurately measured - number and nature of safety incidents, collected taxes and the evolution of housing prices.

Airbnb and similar companies can contribute to preventing undesirable effects by taking selfregulatory measures. Transparency about operated properties and about visitors is essential. Besides the obvious taxation and safety issues, both self-regulation and imposed measures should focus on the main driver of negative impact: commercial parties repurposing residential housing exclusively as tourist accommodation. Some cities have already established maximum rental days; so-called "Power Users" with "multilistings" are another red sign to watch.

\section{Note}

1. Ten hotel executives, 11 destination marketers and ten consultants and trend watchers were invited to answer questions through the software platform Spilter. The platform allowed respondents to anonymously see other answers and to iteratively answer questions and react to other respondents. The response varied from 25 answers, for question 1-14, for questions 2-4.

\section{References}

Airbnb (2012), "Study finds that Airbnb hosts and guests have major positive effect on city economies", Airbnb, San Francisco, CA, 9 November, available at: www.airbnb.nl/press/news/study-finds-that-airbnbhosts-and-guests-have-major-positive-effect-on-city-economies (accessed 13 October 2015).

Airbnb (2013a), "New study: Airbnb community contributes $€ 185$ million to Parisian economy", Airbnb, San Francisco, CA, 12 June, available at: www.airbnb.nl/press/news/new-study-airbnb-communitycontributes-185-million-to-parisian-economy (accessed 13 October 2015).

PAGE $36 \mid$ JOURNAL OF TOURISM FUTURES $\mid$ VOL. 2 NO. 12016 
Airbnb (2013b), "New study: Airbnb community makes Amsterdam economy stronger", Airbnb, San Francisco, CA, 18 June, available at: www.airbnb.nl/press/news/new-study-airbnb-community-makesamsterdam-economy-stronger (accessed 13 October 2015).

Airbnb (2013c), "New study: Airbnb generated \$632 million in economic activity in New York", Airbnb, San Francisco, CA, 22 October, available at: www.airbnb.nl/press/news/new-study-airbnb-generated-632million-in-economic-activity-in-new-york (accessed 13 October 2015).

Airbnb (2013d), "New study: Airbnb community generates \$824 million in economic activity in the UK", Airbnb, San Francisco, CA, available at: www.airbnb.nl/press/news/new-study-airbnb-communitygenerates-824-million-in-economic-activity-in-the-uk (accessed 13 October 2015).

Airbnb (2013e), "New study: Airbnb community contributes \$175 million to Barcelona's economy”, Airbnb, San Francisco, CA, available at: www.airbnb.nl/press/news/new-study-airbnb-community-contributes-175million-to-barcelona-s-economy (accessed 13 October 2015).

Airbnb (2013f), "Impacto económico de Airbnb en Barcelona y en Cataluña", Airbnb, San Francisco, CA.

Airbnb (2014a), "New study: Airbnb community generates \$61 million in economic activity in Portland", Airbnb, San Francisco, CA, available at: www.airbnb.nl/press/news/new-study-airbnb-communitygenerates-61-million-in-economic-activity-in-portland (accessed 13 October 2015).

Airbnb (2014b), "New study: Airbnb community generates $\$ 312$ million in economic impact in LA", Airbnb, San Francisco, CA, 4 December, available at: www.airbnb.nl/press/news/ new-study-airbnb-community-generates-61-million-in-economic-activity-in-portland (accessed 13 October 2015).

Airbnb (2014c), “New study: Airbnb community generates \$51 million in economic impact in Boston”, Airbnb, San Francisco, CA, 19 December, available at: www.airbnb.nl/press/news/new-study-airbnb-communitygenerates-51-million-in-economic-impact-in-boston (accessed 13 October 2015).

Airbnb (2015), "Airbnb community tops $\$ 1.15$ billion in economic activity in New York City", Airbnb, San Francisco, CA, 12 May, available at: www.airbnb.com/press/news/airbnb-community-tops-1-15-billionin-economic-activity-in-new-york-city (accessed 13 October 2015).

Allee, V. (2003), The Future of Knowledge. Increasing Prosperity Though Value Networks, Elsevier, Burlington, MA.

Arias Sans, A. (2015), “Desmuntant Airbnb. Apunts crítics sobre el cas de Barcelona”, 1 July, available at: http://latramaurbana.net/2015/07/01/desmuntant-airbnb-apunts-critics-sobre-el-cas-de-barcelona/\#more1245 (accessed 31 October 2015).

Bahceli, Y. (2015), "Netherlands to make room in rules to stimulate 'sharing economy'”, Reuters, 20 July, available at: www.reuters.com/article/2015/07/20/dutch-sharing-idUSL5N1002JX20150720 (accessed 19 October 2015).

Bauwens, M. (2014), Peer to peer. De circulaire stad, Pakhuis De Zwijger, Amsterdam.

Bishop, P., Hines, A. and Collins, T. (2007), "The current state of scenario development: an overview of techniques”, Foresight, Vol. 9 No. 1, pp. 5-25.

Blickhan, M., Bürk, T. and Grube, N. (2014), "Touristification in Berlin. sublurban”, Zeitschrift für kritische Stadtforschung, Vol. 2 No. 1, pp. 167-80.

Boswijk, A. (2013), "The power of the economy of experiences. New ways of value creation", in Sundo, J. and Sörensen, F. (Eds), Handbook on the Experience Economy, Edward Elgar, Cheltenham, pp. 171-6.

Boswijk, A., Peelen, E. and Olthof, S. (2015), Economie van Experiences, Pearson, Amsterdam.

Botsman, R. (2010/2015), "The case for collaborative consumption", TEDx Sydney, May, available at: www.ted.com/talks/rachel_botsman_the_case_for_collaborative_consumption/ (accessed 29 October).

Botsman, R. (2015), "Defining the sharing economy: what is collaborative consumption - and what isn't?", Fast Company, 27 May, available at: www.fastcoexist.com/3046119/defining-the-sharing-economy-what-iscollaborative-consumption-and-what-isnt (accessed 29 October 2015).

Botsman, R. and Rogers, R. (2010), "Beyond zipcar: collaborative consumption”, Harvard Business Review, Vol. 88 No. 10 , p. 30. 
Botsman, R. and Rogers, R. (2011), What's Mine is Yours. How Collaborative Consumption is Changing the Way We Live, Harper Collins, London.

Brand, R. and Rocchi, S. (2011), Rethinking Value in a Changing. A Model for Strategic Reflection and Business Transformation, Philips Design, Amsterdam.

Cogolludo, S. (2015), "Barcelona condonará la multa a apartamentos ilegales si van a alquiler social", El Mundo, 5 August, available at: www.elmundo.es/cataluna/2015/08/05/55c1d78d46163f32678b45ab. html (accessed 19 October 2015).

Coldwell, W. (2014), "Airbnb's legal troubles: what are the issues?", The Guardian, 8 July, available at: www.theguardian.com/travel/2014/jul/08/airbnb-legal-troubles-what-are-the-issues (accessed 23 October 2015).

Consigli, M., Gallagher, M., Kumar, M., Mehta, N., Purnell, J. and Templeton, R. (2012), "EIS final project: Airbnb", Dartmouth College, Hanover.

Cornelis, A. (1988), Logica Van het gevoel. Stabiliteitslagen in de cultuur als nesteling der emoties, Stichting Essence, Diemen.

Cox, M. (2015), "Adding data to the debate", Amsterdam, 3 September, available at: http://insideairbnb.com/ amsterdam/ (accessed 31 October 2015).

Croft, A. (2015), "Airbnb remains symbol of Barcelona's growing unease with tourism", Skift, 26 August, available at: http://skift.com/2015/08/26/airbnb-remains-symbol-of-barcelonas-growing-unease-withtourism/ (accessed 27 August 2015).

Dickey, M.R. (2014), "Some Airbnb hosts in San Francisco are at risk of eviction", Business Insider, 7 April, available at: www.businessinsider.com/airbnb-hosts-san-francisco-risk-eviction-2014-4? IR = T (accessed 23 October 2015).

Eisenmann, T., Parker, G. and Alstyne, V.W. (2006), "Strategies for two-sided markets", Harvard Business Review, Vol. 84 No. 10, p. 92.

Enger, A., Sandvik, K. and Iversen, E.K. (2014), "Developing scenarios for the Norwegian travel industry 2025", Journal of Tourism Futures, Vol. 1 No. 1, pp. 6-19.

EY España (2015), Impactos derivados del exponencial crecimiento de los alojamientos turísticos en viviendas de alquiler en España, impulsado por los modelos y plataformas ce comercialización P2P, Exceltur, Madrid.

Finley, K. (2013), Trust in the Sharing Economy: An Exploratory Study, Centre for Cultural Policy Studies, University of Warwick, Warwick.

Folger, J. (2015), "The pros and cons of using Airbnb", Investopedia, 30 January, available at: www. investopedia.com/articles/personalfinance/032814/pros-and-cons-using-airbnb.asp (accessed 18 September 2015).

Frenken, K., Meelen, T., Arets, M. and Glind, P.V. (2015), "Smarter regulation for the sharing economy", The Guardian, 20 May, available at: www.theguardian.com/science/political-science/2015/may/20/smarterregulation-for-the-sharing-economy (accessed 31 October 2015).

Füller, H. and Michel, B. (2014), "'Stop being a tourist!' New dynamics of urban tourism in Berlin-Kreuzberg”, International Journal of Urban and Regional Research, Vol. 38 No. 4, pp. 1304-18.

Gansky, L. (2010), Why the Future is Sharing, Penguin Group, New York, NY.

Glind, P.V. (2013), "The consumer potential of collaborative consumption. Identifying (the) motives of Dutch collaborative consumers \& measuring the consumer potential of collaborative consumption within the municipality of Amsterdam", master thesis, Utrecht University, Utrecht.

Green, J. (2007), Democratizing the Future: Towards a New Era of Creativity and Growth, Philips Design, Amsterdam.

Guttentag, D. (2013), "Airbnb: disruptive innovation and the rise of an informal tourism accommodation sector", Current Issues in Tourism, pp. 1-26 (ahead of print).

Hamari, J., Sjöklint, M. and Ukkonen, A. (2015), "The sharing economy: why people participate in collaborative consumption", Journal of the Association for Information Science and Technology. doi: 10.1002/asi.23552 (ahead of print), available at: SSRN 2271971. 
Herman, R., Ardekani, S.A. and Ausubel, J.H. (1990), "Dematerialization", Technological Forecasting and Social Change, Vol. 38 No. 4, pp. 333-47.

Hill, D. (2015), "The secret of Airbnb's pricing algorithm”, IEEE Spectrum, 20 August, available at: http://spectrum.ieee.org/computing/software/the-secret-of-airbnbs-pricing-algorithm (accessed 26 August 2015).

Holte, H.F. and Stene, A.-K. (2014), "A new lease on life: why do Norwegian consumers participate in collaborative consumption? A case study of Airbnb and Bilkollektivet”, master thesis, Norwegian School of Economics, Bergen.

Hooper, J. (2015), "Tourist hotspots around the world are crowded with new visitors - but are they all welcome?", The Guardian, 25 July, available at: www.theguardian.com/business/2015/jul/25/touristhotspots-visitors-developing-countries (accessed 11 August 2015).

Huston, C. (2015), "As Airbnb grows, hotel prices expected to drop MarketWatch", Marketwatch, 13 August, available at: www.marketwatch.com/story/as-airbnb-grows-hotel-prices-expected-to-drop-2015-08-13 (accessed 2 September 2015).

Ikkala, T. and Lampinen, A. (2014), "Defining the price of hospitality: networked hospitality exchange via Airbnb", Proceedings of the Companion Publication of the 17th ACM Conference on Computer Supported Cooperative Work \& Social Computing, ACM, Baltimore, MD, pp. 173-6.

Ikkala, T. and Lampinen, A. (2015), "Monetizing network hospitality: hospitality and sociability in the context of Airbnb", Proceedings of the 18th ACM Conference on Computer Supported Cooperative Work \& Social Computing, ACM, Vancouver, pp. 1033-44.

IPSOS (2013), "Many see sharing one's belongings online as a great way to earn extra money", IPSOS Public Affairs, 20 May, available at: www.ipsos-na.com/download/pr.aspx?id=12731 (accessed 11 October 2015).

Ismail, S., Malone, M., van Geest, Y. and Diamandis, P. (2014), Exponential Organizations: Why New Organizations are Ten Times Better, Faster and Cheaper than Yours (and What to Do About It), Diversion Books, New York, NY.

Jordan, G. (2015), "Airbnb not just a worry, but 'tectonic shift'”, Hotel News Now, 26 August, available at: www.hotelnewsnow.com/Article/16545/Airbnb-not-just-a-worry-but-tectonic-shift (accessed 27 August 2015).

Kagermeier, A., Köller, J. and Stors, N. (2015), "Airbnb als share economy-Herausforderung für Berlin und die Reaktionen der Hotelbranche”, Studien zur Freizeit- und Tourismusforschung.

Kalandides, A., Kather, M. and Köper, P. (2015), LoBÜSch: Lokale Beschäftigungseffekte durch Übernachtungstourismus im Schöneberger Norden, Inpolis, Berlin.

Kaplan, R.A. and Nadler, M.L. (2015), "Airbnb: a Case Study in occupancy regulation and taxation”, No. 82, The University of Chicago Law Review Dialogue, pp. 103-15 (ahead of print).

Kasmir, S. (1996), The Myth of Mondragon: Cooperatives, Politics, and Working Class Life in a Basque Town, SUNY Press, Albany, NY.

Kirkland, R. (2014), "The future of Airbnb in cities", McKinsey \& Company - Insights and Publications, November, available at: www.mckinsey.com/insights/travel_transportation/the_future_of_airbnb_in_cities (accessed 15 September 2015).

Kohda, Y. and Masuda, K. (2013), "How do sharing service providers create value?", Service and Knowledge Innovation Center (SAKI Center), available at: http://saki.siit.tu.ac.th/acis2013/uploads_final/20__ 2d8e033c4413c7764bc013ce1b32dd0d/acis2013-sharing-service-value\%20revisions.pdf (accessed 24 August 2015).

Kok, R. (2015), "NBTC en Airbnb starten gezamenlijke campagne”, Misset Horeca, 6 May, available at: www.missethoreca.nl/hotel/nieuws/2014/11/nbtc-en-airbnb-starten-gezamenlijke-campagne-10159164 (accessed 19 October 2015).

Kostakis, V. and Bauwens, M. (2014), Network Society and Future Scenarios for a Collaborative Economy, Palgrave Macmillan, Basingstoke and New York, NY.

Kurtz, M. (2014), In focus: Airbnb's inroads into the hotel industry, HVS, Houston, TX. 
Lehr, D.D. (2015), "An analysis of the changing competitive landscape in the hotel industry regarding Airbnb", master thesis, Dominican University of California, San Rafael, CA.

Liang, L.J. (2015), “Understanding repurchase intention of Airbnb consumers: perceived authenticity, EWoM and price sensitivity", master thesis, University of Guelph, Guelph.

Lindgren, M. and Bandhold, H. (2009), Scenario Planning. The Link Between Future and Strategy, Palgrave Macmillan, New York, NY.

McNamara, B. (2015), “Airbnb: a not-so-safe resting place”, Colorado Technology Law Journal, Vol. 13 No. 1 , pp. 149-69.

Marzorati, G. (2015), "San Francisco moves to tighten Airbnb law", KQED News, April 23, available at: http://ww2.kqed.org/news/2015/04/23/San-Francisco-Tighten-Airbnb-Law (accessed 23 October 2015).

Maxfield, B. (2015), "Thinking about how to properly tax internet and cloud based businesses", University of Southern California, Los Angeles, CA.

New York State Attorney General (2014), "Airbnb in the city", Office of the New York State Attorney General Eric T. Schneiderman, New York, NY.

Nicholls, R. (2015), "Who bears the cost when your Uber or Airbnb turns bad?", The Conversation, 27 April, available at: https://theconversation.com/who-bears-the-cost-when-your-uber-or-airbnb-turns-bad-39699 (accessed 1 May 2015).

Oates, G. (2015), "Travel Portland CEO on acting like a first-tier destination", Skift, 13 October, available at: http://skift.com/2015/10/13/travel-portland-ceo-on-acting-like-a-first-tier-destination/ (accessed 19 October 2015).

Olma, S. (2014), "Never mind the sharing economy: here's platform capitalism", 16 October, available at: http://networkcultures.org/mycreativity/2014/10/16/never-mind-the-sharing-economy-heres-platformcapitalism/ (accessed 31 October 2015).

Posthumus, W. (2015), "Airbnb draagt jaarlijks $€ 5,5$ miljoen toeristenbelasting af aan Amsterdam", Misset Horeca, 12 October, available at: www.missethoreca.nl/hotel/nieuws/2015/10/airbnb-draagt-jaarlijks-e55miljoen-toeristenbelasting-af-aan-amsterdam-101225727 (accessed 23 October 2015).

Postma, A. (2013), "Anticipating the future of European tourism", in Postma, A., Yeoman, I. and Oskam, J. (Eds), The Future of European Tourism, European Tourism Futures Institute, Leeuwarden, pp. 290-305.

Prahalad, C.K. and Ramaswamy, V. (2004), The Future of Competition: Co-Creating Unique Value with Customers, Harvard Business Press, Boston, MA.

Quijones, D. (2015), "Barcelona just declared war on Airbnb”, Business Insider, 11 August, available at: www. businessinsider.com/barcelona-just-declared-war-on-airbnb-2015-8 (accessed 18 August 2015).

Ramaswamy, V. and Gouillart, F.J. (2010), The Power of Co-Creation: Build it with Them to Boost Growth, Productivity, and Profits, Simon and Schuster, New York, NY.

Ridder, W. (2011), De Wereld Breekt Open, Strategisch Inspelen op de nieuw tijd, Prentice Hall, Amsterdam.

Rifkin, J. (2000), The Age of Access. The New Culture of Hypercapitalism Where All of Life is a Paid-for Experience, Penguin Putnam Inc., New York, NY.

Rifkin, J. (2014), The Zero Marginal Cost Society: The Internet of Things, the Collaborative Commons, and the Eclipse of Capitalism, Palgrave Macmillan, London.

Rochet, J.-C. and Tirole, J. (2004), "Two-sided markets: an overview”, IDEI Working Paper No. 258, Institut d'Économie Industrielle, Toulouse.

Rothkopf, E. (2014), "CCTP-725: remix and dialogic culture", available at: https://blogs.commons. georgetown.edu/cctp-725-fall2014/2014/01/27/transitioning-to-post-postmodernism-a-look-at-twitterairbnb/ (accessed 24 August 2015).

Sabatini, J. (2015), "Airbnb rentals cut deep into SF housing stock, report says", SF Examiner, 14 May, available at: http://archives.sfexaminer.com/sanfrancisco/sf-report-says-units-rented-for-short-termreduce-long-term-housing/Content?oid=2929888 (accessed 19 October 2015). 
Schaal, D. (2015a), "It's beginning: onefinestay pilot with Hyatt highlights sharing economy collaboration to come", Skift, 21 July, available at: http://skift.com/2015/07/21/its-beginning-onefinestay-pilot-with-hyatthighlights-sharing-economy-collaboration-to-come/ (accessed 22 July 2015).

Schaal, D. (2015b), "Airbnb needs to watch out for Booking.com's apartment ambitions", Skift, 6 October, available at: http://skift.com/2015/10/06/airbnb-needs-to-watch-out-for-booking-coms-apartmentambitions/ (accessed 6 October 2015).

Slee, T. (2013), "Some obvious things about internet reputation systems", tomslee.net, available at: http://tomslee. net/wordpress/wp-content/uploads/2013/09/2013-09-23_reputation_systems.pdf (accessed 6 October 2015).

Somerville, H. (2015), "Exclusive: Airbnb to double bookings to 80 million this year", Reuters, 28 September, available at: www.reuters.com/article/2015/09/28/usairbnbgrowthidUSKCNORS2QK20150928 (accessed 30 September 2015).

Soriano, D. (2015), "Barcelona, a la caza del piso turístico: inspectores puerta a puerta y multas de hasta 90.000 euros", Libre Mercado, 15 May, available at: www.libremercado.com/2015-05-15/ barcelona-sale-a-la-caza-del-piso-turistico-con-multas-de-hasta-90000-euros-1276548042/ (accessed 19 October 2015).

Sottek, T. (2014), "Uber has an army of at least 161 lobbyists and they're crushing regulators", The Verge, 14 December, available at: www.theverge.com/2014/12/14/7390395/uber-lobbying-steamroller (accessed 19 October 2015).

Stern, J. (2010), "AirBnb benefits from social proof theory”, josephstern.com, available at: http://josephstern. com/wp-content/uploads/2010/10/Social-Proof-Theory-Paper.pdf (accessed 24 August 2015).

Stors, N. and Kagermeier, A. (2015), "Motives for using Airbnb in metropolitan tourism - why do people sleep in the bed of a stranger?", Regions Magazine, Vol. 299 No. 1, pp. 17-9.

Takhur, S. (2015), "Airbnb shows its hand. What next?", Hospitalitynet, 24 September, available at: www. hospitalitynet.org/news/4071878.html (accessed 30 September 2015).

Tienkamp, P. (2015), "Amsterdamse huurder op straat na onderverhuur via Airbnb", Het Parool, 11 May, available at: www.parool.nl/parool/nl/4/AMSTERDAM/article/detail/4014611/2015/05/11/Amsterdamsehuurder-op-straat-na-onderverhuur-via-Airbnb.dhtml (accessed 23 October 2015).

Turner, M. (2013), "Global head of civic partnerships at Airbnb", A. Boswijk Interviewer, 21 March.

Tuttle, B. (2015), "Marriott's CEO just made a pretty good sales pitch for...Airbnb?", Money.com, 9 July, available at: http://time.com/money/2964290/marriottairbnbarnesorensonneighborhoods/ (accessed 10 September 2015).

Van der Heijden, K. (2005), Scenarios: The Art of Strategic Conversation, John Wiley, New York, NY.

Vekshin, A. (2015), "Airbnb's $\$ 8$ million plus fight over proposed rules in San Francisco”, Skift, 23 October, available at: http://skift.com/2015/10/23/airbnbs-8-million-plus-fight-over-proposed-rules-in-san-francisco/ (accessed 23 October 2015).

Vincent, J. (2015), "Airbnb starts collecting tourist tax in Paris, its most popular destination", The Verge, 26 August, available at: www.theverge.com/2015/8/26/9209603/airbnb-tourist-tax-paris (accessed 26 August 2015).

Wallsten, S. (2015), "The competitive effects of the sharing economy: how is Uber changing taxis?", Researchgate, July, available at: www.researchgate.net/publication/279514652_The_Competitive_Effects_ of_the_Sharing_Economy_How_is_Uber_Changing_Taxis (accessed 4 September 2015).

Yannopoulou, N., Moufahim, M. and Bian, X. (2013), "User-generated brands and social media: Couchsurfing and AirBnb”, Contemporary Management Research, Vol. 9 No. 1, pp. 85-90.

Yeoman, I. and McMahon-Beattie, U. (2005), "Developing a scenario planning process using a blank piece of paper”, Tourism and Hospitality Research, Vol. 5 No. 3, pp. 273-85.

Yeoman, I., Tan Li Yu, , R., Mars, M. and Wouters, M. (2012), 2050 - Tomorrow's Tourism, Channelview, Bristol, CT.

Yeoman, I., Davies, J., Wheatley, C., Mars, M.S.H. and Butterfeield, S. (2012), Tourism2050: Scenarios for New Zealand, Victoria University of Wellington, Wellington.

Zervas, G., Proserpio, D. and Byers, J. (2014), "The rise of the sharing economy: estimating the impact of Airbnb on the hotel industry", research paper, Boston U. School of Management, Boston, MA. 
Zervas, G., Proserpio, D. and Byers, J.W. (2015), "A first look at online reputation on Airbnb, where every stay is above average", Collaborative Economy, 28 January, available at: http://collaborativeeconomy.com/wp/ wp-content/uploads/2015/04/Byers-D.-Proserpio-D.-Zervas-G.2015.A-First-Look-at-Online-Reputationon-Airbnb-Where-Every-Stay-is-Above-Average.Boston-University.pdf (accessed 24 August 2015).

Ziegert, S. (2013), “Großstädte wollen private Ferienwohnungen verbieten”, Die Welt, 3 August, available at: www.welt.de/finanzen/immobilien/article118621035/Grossstaedte-wollen-private-Ferienwohnungenverbieten.html (accessed 24 October 2015).

\section{Corresponding author}

Jeroen Oskam can be contacted at: j.oskam@hotelschool.nl

For instructions on how to order reprints of this article, please visit our website: 